\title{
Mineral trioxide aggregate in primary teeth pulpotomy. A systematic literature review
}

\author{
Miguel-Angel Simancas-Pallares ${ }^{1}$, Antonio-José Díaz-Caballero ${ }^{2}$, Luz-Mayda Luna-Ricardo ${ }^{3}$ \\ ${ }^{1}$ Dentist. M.Sc. (Student) Clinical Epidemiology. Research Department Assistant. Faculty of Dentistry. University of Carta- \\ gena \\ ${ }^{2}$ Dentist. PhD (Student) Biomedical Sciences. Titular Professor. Faculty of Dentistry. University of Cartagena \\ ${ }^{3}$ Dentist. Pediatric Dentistry Specialist. Titular Professor. Faculty of Dentistry. University of Cartagena
}

Correspondence:

Departamento de Investigaciones

Facultad de Odontología

Universidad de Cartagena.

Campus Ciencias de la Salud, Zaragocilla.

Cartagena de Indias. Colombia.

simancaspallares@gmail.com.

Received: 08/09/2009

Accepted: 27/03/2010

\author{
Simancas-Pallares MA, Díaz-Caballero AJ, Luna-Ricardo LM. Mineral \\ trioxide aggregate in primary teeth pulpotomy. A systematic literature \\ review. Med Oral Patol Oral Cir Bucal. 2010 Nov 1;15 (6):e942-6. \\ http://www.medicinaoral.com/medoralfree01/v15i6/medoralv15i6p942.pdf

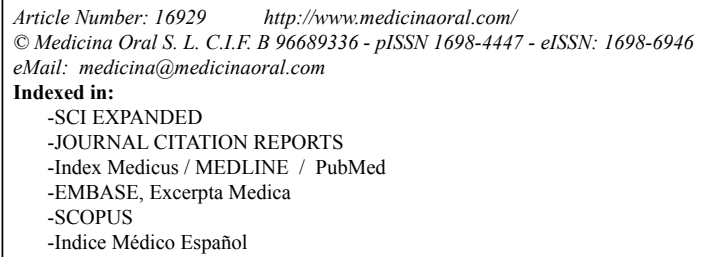

\begin{abstract}
Evidence-based dentistry is a critical evaluation, awareness of the available evidence to improve decision making about the care of individual patients and / or communities. Objective: To systematically analyze the available scientific literature on clinical and radiographic results of two materials used in pulpotomy in primary teeth: formocresol and mineral trioxide aggregate. Materials and methods: It was identified relevant publications through a search of electronic databases such as MEDLINE (Ovid) and The Cochrane Library. To be included in the review, studies had to define the material used in child patients with pulp exposure by caries or tooth-alveolar trauma. Results: Of the 21 articles obtained in the initial phase of the review, only 19 were available in full text and of these only met the requirements for inclusion 6 items, which were confronted, analyzed and discussed later. Conclusions: The clinical evidence available showed significant differences regarding the use of a material or another. In addition to the findings of clinical follow - radiographic and taking into account the potential toxicity of formocresol suggest the use of mineral trioxide aggregate pulpotomy of primary teeth.
\end{abstract}

Key words: Pulpotomy, dental pulp, randomized controlled trial.

\section{Introduction}

The progress in understanding of molecular and cellular changes during dental development and how are they imitated during tissue repair, offers the opportunity of evaluating the biological validity of different strategies in vital pulp therapy. Under this perspective, and based on a good clinical history to arrive at a proper diagnosis, different pulp therapy options, such as indirect pulp treatment (IPT), direct pulp treatment (DPT), pulpotomy and pulpectomy are available (1).
If a tooth with a carious lesion remains untreated or, is inadequately treated, a bacterial invasion of the coronal pulp will occur originating an inflammatory response at that level. In this stage the inflammation is confined to this space, but if the affected tissue is removed and the entrance to the root canals is covered with an appropriate agent, the remaining tissue is capable of recovering. This capability is used when a molar with a pulp exposure is treated with vital pulp therapy. In this manner, the main objective of pulp treatment is to preserve the 
integrity and health of oral tissues. However, if a tooth can continue functioning without vital coronal pulp; it is desirable to preserve pulp vitality; therefore, the objective of vital pulpotomy is to treat reversible injury (2). Pulpotomy is one the most frequently used treatments to maintain primary molars with carious involvement, symptomless or with reversible pulpitis which otherwise would be extracted. Its objective is to preserve radicular pulp, avoid pain, inflammation and, maintain the tooth (3).

Formocresol (FC) was first used in 1930 by Sweet who reported a success rate of $97 \%$. It produces an area of necrosis adjacent to the lesion. The tissue is often altered by formaldehyde and appears "fixed" in situ and therefore is not subjected to liquefaction necrosis in the root canal. It is the most frequently used pulp capping agent in deciduous molars, however, formaldehyde which is the most important component of formocresol, shows certain risk of systemic distribution after its use (4). Several concerns have been expressed recently with respect to the use of formocresol in pulpotomies because of the following: pulp response with inflammation and necrosis, citotoxicity, systemic disturbances, possible mutagenicity and carcinogenicity and altered immune response.

However with the advance of technology, different compounds are being studied in order to find one that provides better clinical efficacy without secondary effects, among them, the following have been widely reported in the scientific literature: electro surgery, Er:YAG laser, calcium hydroxide, glutaraldehide, ferric sulfate, collagen enriched solution, bone morphogenetic proteins or mineral trioxide aggregate (M.T.A.) (3).

The objective of this systematic review of the literature is to compare the available evidence on the clinical and radiographic effects of formocresol with mineral trioxide aggregate in deciduous molars treated with pulpotomy.

\section{Materials and Methods}

A computarized search of the literature was done using MEDLINE (Ovid: 1960-2008) (Table 1), and The Cochrane Library. Randomized controlled trials which compared formocresol and/or mineral trioxide aggregate pulpotomies in primary teeth, were selected. The titles and abstracts of the studies were evaluated according to relevance after obtaining the full text articles. The search ended in January 2009.

The inclusion criteria were: studies that evaluated pulp treatment of primary molars with vital pulp exposure due to caries or trauma which included drugs such as formocresol and/or mineral trioxide aggregate, follow up time of at least 6 months, symptomless teeth without indication of irreversible pulpitis, restorable teeth, and evaluation by clinical and radiographic methods. Exclusion criteria: lack of randomization of the subjects, animal or in vitro studies, absence of comparison between the treatment groups, the article could not be found.

Initially we found 21 articles for possible inclusion, when the criteria were applied, 6 articles (randomized controlled clinical trials) were selected for further analysis (Table 2).

Table 1. Search strategy in MedLine (Ovid). FC: Formocresol.

\begin{tabular}{|c|c|c|}
\hline & KEYWORDS & RESULTS \\
\hline 1 & Pulpotomy & 296 \\
\hline 2 & Pulp therapy & 179 \\
\hline 3 & Primary molar & 290 \\
\hline 4 & Formocresol & 117 \\
\hline 8 & 1 and 3 & 65 \\
\hline 9 & 1 or 3 & 521 \\
\hline 10 & 4 and 1 and 3 & 41 \\
\hline 11 & 4 or 1 or 3 & 567 \\
\hline 12 & FC & 21668 \\
\hline 13 & 8 and 9 and 10 and 11 and 12 & 21 \\
\hline
\end{tabular}

Table 2. Evidence that compare formocresol (FC) vs mineral trioxide aggregate (MTA) pulpotomy outcomes.

\begin{tabular}{|c|c|c|c|c|c|c|c|c|c|}
\hline \multirow[b]{2}{*}{ ARTICLE } & \multirow{2}{*}{$\begin{array}{c}\text { AGE } \\
\text { YEARS }\end{array}$} & \multicolumn{2}{|c|}{$\begin{array}{l}\text { TREATED } \\
\text { MOLARS }\end{array}$} & \multicolumn{2}{|c|}{$\begin{array}{l}\text { CLINICAL } \\
\text { OUTCOMES }\end{array}$} & \multicolumn{2}{|c|}{$\begin{array}{l}\text { RADIOGRAPHIC } \\
\text { OUTCOMES }\end{array}$} & \multirow{2}{*}{$\begin{array}{c}\text { TIME } \\
\text { MONTHS }\end{array}$} & \multirow{2}{*}{$\begin{array}{c}\text { St. SIG- } \\
\text { NIF. } \\
p\end{array}$} \\
\hline & & FC & MTA & FC & MTA & FC & MTA & & \\
\hline Agamy et al, 2004. & 6.1 & 20 & 20 & $18(90)$ & $19\left(100^{*}\right)$ & $18(90)$ & $19(100)$ & 12 & $>0.05$ \\
\hline Holan et al, 2005. & 6.2 & 29 & 33 & $24(83)$ & $32(97)$ & $24(83)$ & $32(97)$ & $\leq 74$ & $>0.05$ \\
\hline Farsi et al, 2005. & 6.0 & 36 & 38 & $35(97.2)$ & $38(100)$ & $31(86.8)$ & $38(100)$ & 24 & 0.03 \\
\hline Naik y Hedge, 2005. & N.E. & 23 & 24 & $23(100)$ & $24(100)$ & $23(100)$ & $24(100)$ & 6 & N.A \\
\hline Aienehchi et al, 2005 & 6.4 & 57 & 43 & $57(100)$ & $43(100)$ & $47(90.5)$ & $43(100)$ & 6 & 0.03 \\
\hline Noorollahian et al, 2008 & 6.0 & 27 & 29 & $18(66)$ & $18(66)$ & $18(62)$ & $17(58)$ & 24 & $>0.05$ \\
\hline
\end{tabular}

Treated molars: molar teeth treated in each technique. Clinical outcomes: frequency of clinical success. Radiographic outcomes: frequency of radiographic success. Time (Months): follow-up months. St Signif: statistical significance of the outcomes represented by the "p-value". Parentheses: success rate of each material. *One exfoliated molar, for this reason, authors consider $100 \%$ success. 
Afterwards, the articles were indexed in a digital data base and each one was evaluated taking as reference data, the authors, title, journal, year, volume, number, month and, pages. The methodology used was detailed and emphasis was also placed on the results (number of teeth, success rate, failure rate, frequencies). The results were confronted and analyzed to be discussed later.

\section{Results and Discussion}

Formocresol was first introduced in 1904 (5) by Buckley; since then it is considered as the "gold standard" with which other drugs must be compared in pulpotomy experiments in primary molars. It became the most widely used drug due to its bacteriostatic and fixative properties, with a success rate varying from $55 \%$ to $98 \%$. However, other authors suggest that the clinical and radiographic efficacy of formocresol varies between 70 to $97 \%$ (6). Its chemical composition of formaldehyde (mutagenic and carcinogenic) and cresol (caustic agent), elicits concerns, even though there is no evidence that its systemic distribution can cause disease (7).

The histological response of the pulp after formocresol treatment seems to be unfavorable. Several researchers have reported that after application of formocresol, there is fixation of the coronal third in the radicular pulp and chronic inflammation in the middle third, leaving the apical third unaltered or vital. Other authors report that the remaining pulp tissue is partially or totally necrotic. Frequently, the pulp remains half vital, half necrotic and chronically inflamed. Although many studies published in the 90's questioned the safety and efficacy of formocresol, different researchers agree that it is potentially mutagenic but still is the drug of choice for pulpotomies in the deciduous dentition.

However, the International Agency for Research on Cancer (IARC), evaluating the available literature, concluded that there is sufficient evidence, in animal and human experimentation, to classify formaldehyde as carcinogenic. IARC recommended the substitution of formaldehyde containing materials for safer alternatives (8).

In spite the efforts the scientists are doing searching for an adequate replacement material for FC, the studies on a new material called Mineral Trioxide Aggregate (M.T.A.), developed by Torabinejad et al (9) at Loma Linda University (Loma Linda University, CA, USA) suggest excellent results when is used for pulpotomies in primary teeth.

It was only in 1998, that the Food and Drug Administration of the United States approved M.T.A as a therapeutic endodontic material for human use (10). M.T.A is a powder consisting of tricalcium silicate, bismuth oxide, dicalcium silicate, tetracalcium aluminate, tetracalcium aluminate ferrate and dehydrated calcium sulphate.

Histological studies by Torabinejad et al (11) used MTA to repair endodontic perforations; the material showed biocompatibility and very little inflammation, even when the material extruded from the perforation site. Recently, MTA was introduced as a potential alternative agent to formocresol with characteristics of liberation of cytokins from the bone cells, induction of hard tissue formation, odontogenic effect on the pulp, antimicrobial properties and preservation of pulp integrity after pulp capping or pulpotomy, without citotoxic effects (12). Agamy et al in 2004 (13), in a randomized controlled study, selected 72 molars in 24 children for clinical and radiographic study. The selected teeth were randomly assigned and divided in to three groups according to the pulp filling material used (Gray MTA, White MTA or formocresol). An additional group of 15 teeth was prepared for serial extraction in order to carry out histological evaluation. The pulpotomies were performed by the same operator and the results evaluated by two pediatric dentists who did not know which tooth had which material was being evaluated (blind study).

The results showed that all 60 teeth were considered clinically and radiographically successfully at the first month of postoperative evaluation. At three months, a tooth from the white M.T.A. group was diagnosed as a clinical and radiographic failure due to an abscess, and was extracted. The 59 remaining teeth were considered as clinically and radiographically successful at the 3 month postoperative evaluation. At 6 months, a tooth from the Gray M.T.A. groups was lost due to exfoliation and the remaining 58 teeth were diagnosed as clinically and radiographically successful. At the 12 month evaluation, the 19 teeth from the Gray M.T.A. group were all considered clinically and radiographically successful. In the White M.T.A. group, 3 teeth were diagnosed as clinical and radiographic failures. The 16 remaining teeth in the Gray M.T.A. group were evaluated as clinical and radiographic success. Two teeth in the formocresol group were diagnosed as clinical and radiographic failures. When statistical tests were applied, there were no statistical significant differences between one material and the other.

Farsi et al in 2005 (14) in a randomized controlled trial, compared the clinical and radiographic results of primary molars treated formocresol pulpotomy or MTA pulpotomy; they selected a randomized sample of 100 children for the study. A total of 120 teeth were included and the coronal pulp was amputated using a conventional pulpotomy technique. All the groups were treated under the same protocol, except for the application of the material. The teeth were divided in two equal groups, one group received MTA as filling material and FC was used in the other group.

Their results showed that of the 120 treated teeth, only 74 were available for clinical and radiographic evaluation through the follow up period (24 months). During 
the first 12 months there were no clinical or radiographic pathologies in either group. Radiographic pathology was evident in 4 cases of the $38(10.51 \%)$ patients treated with FC; on the other hand, there were no evident clinical symptoms of failure in this stage. Of the cases reported as failures, 3 teeth revealed internal resorption and one tooth showed furcation involvement.

After twelve months the results indicated that none of the MTA treated teeth presented evidence of radiographic pathology or clinical signs of failure. The difference, however, was not statistically significant $(\mathrm{p}=0.64)$. After twelve months, the FC group showed 5 cases of pulpal pathology (13.2\%), with only one case of pain. All of the reported failures showed internal resorption and, two of them revealed furcation involvement. On the other hand, all of the 38 MTA treated teeth were considered as clinically and radiographically successful. The statistical difference between the two groups after 24 months of evaluation was evident as it regards to radiographic pathology $(\mathrm{p}=0.031)$.

Holan et al in 2005 (15) in a comparative study of formocresol versus MTA pulpotomies, selected a total of 64 primary molars which received pulpotomies from a sample of 35 children randomly assigned by the toss of a coin to either one of the two groups. In case one of the children had two molars needing pulpotomies, the other molar was assigned to the alternative group. If a child needed 3 pulpotomies, the capping material was again decided by the toss of a coin. The children came back for re evaluation every 6 months for a total average of 38 months.

Their results revealed that of the 64 molars treated, 62 teeth in 33 children were available for evaluation of success/failure rate. Two molars in two patients, both from the FC group were excluded from the study because the patients never returned for the follow up visits. The capping material used was MTA in 33 molars and FC in 29 molars. The failures were detected in 6 teeth after an average follow up period of 16 months. Twenty nine teeth with successful treatment were followed until their normal exfoliation with an average follow up period of 33 months. The remaining 27 successfully treated teeth had an average follow up period of 49 months with no difference between the experimental and the control group.

The success rate of pulpotomies in all the teeth for this study was $90 \%$. MTA was successful in $97 \%(32 / 33)$ and FC was successful in $83 \%$ (24/29) without statistical significant difference between the two materials. The follow up evaluation revealed 6 failures (10\%): 5 of them in the FC group and 1 in the MTA group.

The most common radiographic finding among all teeth was obliteration of the root canals $55 \%$ (34/62). It was found in $58 \%$ of the MTA treated teeth (19/33) and in $52 \%(15 / 29)$ of the FC treated teeth, followed by internal resorption which was observed in 8 teeth (6 with $\mathrm{FC}$ and 2 with MTA). The least frequent finding was a dentinal bridge which was detected on tooth treated with MTA. Naik and Hedge in 2005 (16) in a randomized controlled trial included 50 symptomless primary molars with deep carious lesions and randomly assigned for treatment with FC or with MTA (25 teeth per group). All teeth were restored with stainless steel crowns and clinical and radiographic controls were done during 6 months (Controls at 1-3-6 months).

The results revealed that of the 50 teeth selected, 3 were not available for follow up after the first month. The follow up appointments after the first, third and sixth months did not show any clinical or radiographic pathological findings on the rest of the 47 teeth, therefore, no statistical analysis was carried out due to the success of the treatment. The only significant finding was color change in $60 \%$ of the teeth in which MTA was the medicament used after 24 hours, but was later masked when the stainless steel crown was placed.

Peng et al in 2006 (17) did a review of the literature applying the meta analysis technique and compared FC and MTA through six articles evaluated by means of the Jadad scale and found that there was a statistically significant difference between the success rates of FC and MTA in molars treated with pulpotomy. The clinical and radiographical evaluations indicated that MTA was superior to FC with a lower failure rate. They concluded that MTA induced a less undesirable response and could be a good substitute for pulpotomies in primary teeth.

Aeinehchi et al in 2007 (18) in a randomized controlled study compared the effects of MTA and FC in primary molars treated with pulpotomy. 126 children between the 5 and 9 years of age and who required pulpotomy, were selected. The patients were assigned by a random number automatically originating the control or the experimental group. A total of 75 patients were assigned to the formocresol group and 51 to the MTA group. Of the 126 patients, 26 did not return for the follow up appointments (18 FC and $8 \mathrm{MTA}$ ), resulting in 100 cases for analysis. At three months of follow up there were no signs of failure in neither of the groups. A radiographic evaluation of the teeth revealed root resorption in one of the 57 cases in the FC group. This finding was not observed in the MTA group. After 6 months of follow up there was no clinical failure, however in 6 of the 57 cases treated with FC, root resorption was observed and in 4 of the cases the periodontal tissues were affected. The MTA group did not present such characteristics. The differences between the groups were statistically significant.

Noorollahian et al in 2008 (19) in a randomized controlled clinical study compared the results of MTA versus $\mathrm{FC}$ in pulpotomized primary teeth in 46 children 
between the ages of 5 and 7 years. Sixty lower second primary molars received pulpotomy treatment (FC MTA). The teeth were randomly assigned to the control or to the experimental group (30 teeth each) using a random table. The data was analyzed during 24 months to evaluate the success rate during the different follow up periods (6, 12, and 24 months).

Their findings indicate that at 6 months of follow up, 43 children with a total of 56 teeth, returned for postoperative control. All the teeth treated in both groups $(\mathrm{FC}=27-\mathrm{MTA}=29)$ were clinically and radiographically successful. At the 12 month follow up visit, 43 children with 53 teeth were available for clinical and radiographic evaluation. The formocresol treated teeth (27) were clinically and radiographically successful. The MTA treated teeth (29) were clinically successful but the radiographic examination revealed one failure, which consisted of furcation involvement. At the 24 month follow up 27 children with 36 teeth were available for postoperative control. The formocresol (18) treated teeth were clinically and radiographically successful. The MTA (18) treated teeth were clinically successful. The radiographic follow up revealed one failure, furcation involvement, in another one of the molars treated with MTA. Obliteration of the pulp canals observed in 1 of the MTA treated teeth and in 4 of the formocresol treated teeth.

\section{Conclusions}

The present available literature is an important tool for rationalizing correct clinical decisions. This is why the scientific efforts to improve do not stop and include new concepts and treatment strategies in order to reduce the incidence of adverse effects and increase their biocompatibility.

Based on the scientific evidence found until now, human primary molars with reversible pulpitis, with pulp exposure due to caries or to dentoalveolar trauma, can be treated with formocresol or mineral trioxide aggregate, with similar success rates but with significant differences as is evidenced by a recent meta-analysis. Considering the frequency of appearance of radiographic findings, such as furcation involvement, and its questionable citotoxicity, as it regards to the use of formocresol, the authors suggest the application of mineral trioxide aggregate.

\section{Bibliografía}

1. Fuks AB. Current concepts in vital primary pulp therapy. Eur $\mathbf{J}$ Paediatr Dent. 2002;3:115-20.

2. Tziafas D, Smith AJ, Lesot H. Designing new treatment strategies in vital pulp therapy. J Dent. 2000;28:77-92.

3. American Academy of Pediatric Dentistry. Guideline on pulp therapy for primary and young permanent teeth. Pediatr Dent. 2004;26:115-9.

4. Sweet CA. Procedure for treatment of exposed pulp of deciduous teeth. J Am Dent Assoc 1930;17:1150-4.
5. Buckley JP. The chemistry of pulp decomposition with a rational treatment for this condition and its sequelae. Am J Dent. 1904;3:76471.

6. Sonmez D, Sari S, Cetinbaş T. A Comparison of four pulpotomy techniques in primary molars: a long-term follow-up. J Endod. 2008;34:950-5.

7. Burnett S, Walker J. Comparison of ferric sulfate, formocresol, and a combination of ferric sulfate/formocresol in primary tooth vital pulpotomies: a retrospective radiographic survey. ASDC J Dent Child. 2002;69:44-8,12.

8. International Agency for Research on Cancer, World Health Organization. Disponible en: http://www.iarc.fr/en/media-centre/pr/2004/ pr153.html; Julio 10 de 2009.

9. Torabinejad M, Hong CU, McDonald F, Pitt Ford TR. Physical and chemical properties of a new root-end filling material. J Endod. 1995;21:349-53.

10. Schwartz RS, Mauger M, Clement DJ, Walker WA 3rd. Mineral trioxide aggregate: a new material for endodontics. J Am Dent Assoc. 1999;130:967-75.

11. Torabinejad M, Pitt Ford TR, McKendry DJ, Abedi HR, Miller DA, Kariyawasam SP. Histologic assessment of mineral trioxide aggregate as a root-end filling in monkeys. J Endod. 1997;23:225-8.

12. Tziafas D, Pantelidou O, Alvanou A, Belibasakis G, Papadimitriou S. The dentinogenic effect of mineral trioxide aggregate (MTA) in short-term capping experiments. Int Endod J. 2002;35:245-54.

13. Agamy HA, Bakry NS, Mounir MM, Avery DR. Comparison of mineral trioxide aggregate and formocresol as pulp-capping agents in pulpotomized primary teeth. Pediatr Dent. 2004;26:302-9.

14. Farsi N, Alamoudi N, Balto K, Mushayt A. Success of mineral trioxide aggregate in pulpotomized primary molars. J Clin Pediatr Dent. 2005;29:307-11.

15. Holan G, Eidelman E, Fuks AB. Long-term evaluation of pulpotomy in primary molars using mineral trioxide aggregate or formocresol. Pediatr Dent. 2005;27:129-36.

16. Naik S, Hegde AM. Mineral trioxide aggregate as a pulpotomy agent in primary molars: An in vivo study. J Indian Soc Pedod Prev Dent. 2005;23:13-6.

17. Peng L, Ye L, Tan H, Zhou X. Evaluation of the formocresol versus mineral trioxide aggregate primary molar pulpotomy: a meta-analysis. Oral Surg Oral Med Oral Pathol Oral Radiol Endod. 2006;102:e40-4.

18. Aeinehchi M, Dadvand S, Fayazi S, Bayat-Movahed S. Randomized controlled trial of mineral trioxide aggregate and formocresol for pulpotomy in primary molar teeth. Int Endod J. 2007;40:261-7.

19. Noorollahian H. Comparison of mineral trioxide aggregate and formocresol as pulp medicaments for pulpotomies in primary molars. Br Dent J. 2008;204:E20.

\section{ACKNOWLEDGMENTS}

The authors thanks to Dr. Eliecer Eidelman. Professor, School of Dental Medicine, Hebrew University of Jerusalem, for their invaluable assistance in reading the document, suggestions and all their support. 